\title{
Prostatic Basal Cell Hyperplasia
}

National Cancer Institute

\section{Source}

National Cancer Institute. Prostatic Basal Cell Hyperplasia. NCI Thesaurus. Code C5593.

A type of prostatic hyperplasia. It is characterized by the presence of nodules of dark basal cells around residual prostatic secretory cells. 